\title{
蛍光ランブを用いた植物工場の照明設計法に関する研究
}

\author{
池田彰・谷村泰宏・中山繁樹・岩尾憲三* \\ 三菱電機中央研究所 $\cdot *$ 中部電力電気利用技術研究所
}

\section{Study on Lighting Design in Plant Factory Using Fluorescent Lamps}

\author{
Akira Ikeda, Yasuhiro Tanimura, Shigeki Nakayama \\ and Kenzo IwAO* \\ Central Laboratory, Mitsubishi Electric Corp., Amagasaki 661, Japan \\ * Electrotechnology Applicaiions R\&D Center, Chubu Electric Power Co., Inc., \\ Nacori-ku, Nagoya 459, Japan
}

\begin{abstract}
We have developed a plane growth chamber equipped with fluorescent lamps to closely illuminate plants, and painted the inside white $(0.8$ reflectance) to effectively use the reflected light (close illumination method). In this paper, the characteristics of the close illumination method using fluorescent lamps were investigated experimentally and theoretically.

(1) A simulation of the coefficient of utilization $(f)$, which indicates the light utilization efficiency in the growth room, agreed well with the experimental results. When the room shape coefficient became smaller, the value of $f$ increased remarkably. Since the room shape coefficient was proportional to lamp height, close illumination was found to be effective for improvement of $f$.

(2) In a growth room (2.25 m wide, $5.4 \mathrm{~m} \mathrm{long})$ with a set lamp height of $30 \mathrm{~cm}, f$ was found to be about 1.7; nearly 3 times higher than the value found by the illumination method using high brightness lamps, such as high pressure sodium lamps. Thus, the light utilization efficiency of the growth room could be greatly by the close illumination method using fluorescent lamps.

(3) The light intensity of the horizontal plane at a distance of $0-25 \mathrm{~cm}$ above the floor, was uniformly within $20 \%$ difference.

(4) In the case of plants present in the growth room, the simulation of the light intensity of the horizontal plane at the highest part of lettuce (index light intensity), predicted well the experimental results. When the entire floor was covered with lettuce, the index light intensity was about $35 \%$ lower than the initial value.
\end{abstract}

(Received August 26, 1991)

1991 年 8 月 26 日受付

\section{緒}

人工光型の植物工場（または種苗工場）において，照 明の最適化は植物成育に対してのみならず, 電力コスト に係わる重要課題である1). 人工光源を用いた照明は本 来人間を対象としたものであり，視覚および心理的な条 件を満足するように設計される、いっぽう，植物栽培に おける照明では, 成育室の照明効率を高め, かつ葉群の 受光効率を向上させて光利用効率を高めることが重要で ある。

Vol. 30, No. 1 (1992)
筆者らは，このような観点から，光源として葉焼けの 原因となる熱線含量が少なく，光環境要因の制御が容易 な蛍光ランプを用いて，照明の方向，強度および時間が 植物成育に及ぼす影響について調べてきた ${ }^{2 \sim 7)}$. その結 果, ランプと床面の距離を数十 $\mathrm{cm}$ に近接させ, 内面を 白色塗装（反射率 0.8）し，反射光を有効に利用した近 接照明方式により，レタスなどの葉菜類を省電力で高速 栽培できることを明らかにしだ8.

人工光源を用いた照明に関する報告は, 鶴岡・高过ら による立体式植物工場の照明設計法9) や Ruthner によ る高効率照明法 ${ }^{10)}$ があるが少ない. とくに蛍光ランプを 
用いた植物工場の照明設計に関する研究はほとんど見あ たらない.

そこで，本報では蛍光ランプを光源とした植物工場ま たは種苗工場における照明設計の基礎資料を得るため に，近接照明方式の照明計算法について検討するととも に, 成育室の照明率, 高さ方向の光強度分布および植物 成長に伴う光強度の変化などを調べ，いくつかの新しい 知見を得たので報告する。

\section{蛍光ランプによる近接照明特性の}

$$
\text { シミュレーション }
$$

\section{1. 植物が成育室に設置されない場合の照明計算法}

照明率 $f$ （成育室の光利用効率を示す係数）は，（1） 式で定義される.なお，植物栽培での光強度単位は一般 に光量子密度が用いられるが, 同一ランプの場合, 光量 子密度と照度は一定の比例関係にあることから以下では 照度を用いた。

$$
E=(f \cdot U \cdot F) / S
$$

ここで, $E$ は床面照度 $\left(1 \mathrm{~m} / \mathrm{m}^{2}\right), f$ は照明率 $($ 一), $U$ はランプ保守率 (一), $F$ はランプ全光束量 $(1 \mathrm{~m}), S$ は床面積 $\left(\mathrm{m}^{2}\right)$ である.

Fig. 1 に示したように， $n$ 本の蛍光ランプを天井に配 置した場合, ランプからの全光束量 $(F)$ は壁面, 天井面 および床面にそれぞれ $F_{1}, F_{2}$ および $F_{3}$ に分配される. このとき成育室の照明率 $(f)$ は $(2)$ 式から算出される ${ }^{11)}$.

$$
f=f_{1} \cdot\left(F_{1} / F\right)+f_{2} \cdot\left(F_{2} / F\right)+f_{3} \cdot\left(F_{3} / F\right)
$$

ここで，光束分配率 $\left(F_{1} / F\right),\left(F_{2} / F\right)$ および $\left(F_{3} / F\right)$ は, ランプから壁面, 天井面および床面への配光角度 $Z_{i j}$ を用いて，(3)式から算出した。 このとき，ランプは 天井面に接近して配置されるので, 天井面への配光角度 $Z_{2 j}$ は $\pi$ ラジアンとした.

$$
\left(F_{i} / F\right)=\sum_{j=1}^{n}\left(Z_{i j} / 2 \pi n\right) \quad i=1,3, j=1, n
$$

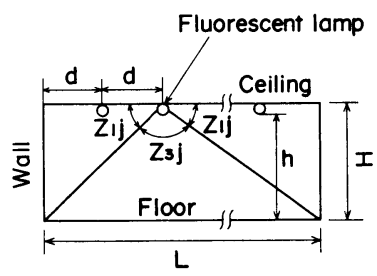

$$
\begin{aligned}
& Z_{1 j}=\tan ^{-1}(H / j \cdot d)+\tan ^{-1}(H /(L-j \cdot d)) \\
& Z_{2 j}=\pi \\
& Z_{3 j}=\pi-Z_{1 j}
\end{aligned}
$$

Fig. 1 Distribution of radiation from fluorescent lamp.

$10(10)$
また，(2)式において， $f_{1}, f_{2}$ および $f_{3}$ はランプの全 光束が壁面，天井面および床面の単一面のみに照射され た場合の照明率であり，Moon の照明計算式，(4)〜 (6) 式により算出できる ${ }^{11,12)}$. 式中, $\rho_{1}, \rho_{2}$ および $\rho_{3}$ は壁 面，天井面および床面の反射率である， $H$ および $h^{\prime}$ は 天井面高さおよび天井面下の距離である．また $K r$ は室 形状係数であり，(7) 式で定義される.

$$
\begin{aligned}
f_{1}= & \left(\rho_{1} / 4 K r\right) \cdot\left[\left(1 / A_{1}\right)+\left(E / A_{1}\right) \cdot\left\{\left[A _ { 2 } \cdot \left(2-\rho_{1}\right.\right.\right.\right. \\
& \left.\times\left(1+\rho_{3}\right)\right) \cdot \cos h(2 K r \cdot B)+2 A_{2} \cdot B \cdot \sin h(2 K r \\
& \left.\times B)+A_{3} \cdot\left(2 \rho_{2}-\rho_{1} \cdot\left(1+\rho_{3}\right)\right)\right] \cdot \sin h(2 K r \cdot B \\
& \left.\times h^{\prime} / H\right)-\left[A_{2} \cdot\left(2-\rho_{1} \cdot\left(1+\rho_{3}\right)\right) \cdot \sin h(2 K r \cdot B)\right. \\
& \left.+2 K r \cdot B \cdot \cos h(2 K r \cdot B)+2 \rho_{2} A_{3} \cdot B\right] \\
& \left.\left.\times \cos h\left(2 K r \cdot B \cdot h^{\prime} / H\right)\right\}\right] \\
A_{1}= & 1-\rho_{1}, \quad A_{2}=1-\rho_{2}, \quad A_{3}=1-\rho_{3}, \\
B= & \left(1-\rho_{1}\right)^{1 / 2} \\
E= & {\left[2\left(1+\rho_{2} \cdot \rho_{3}\right)-\rho_{1} \cdot\left(1+\rho_{2}\right) \cdot\left(1+\rho_{3}\right)\right] } \\
& \times \sin h(2 K r \cdot B)+2 \cdot B \cdot\left(1-\rho_{2} \cdot \rho_{3}\right) \\
& \times \cos h(2 K r \cdot B) ;-1 \\
f_{2}= & \rho_{2} \cdot E \cdot\left[\left(\left(2-\rho_{1} \cdot\left(1+\rho_{3}\right)\right) \cdot \sin h(2 K r \cdot B)+2 B\right.\right. \\
& \times \cos h(2 K r \cdot B)] \cdot \cos h\left(2 K r \cdot B \cdot h^{\prime} / H\right) \\
& -\left[\left(2-\rho_{1} \cdot\left(1+\rho_{3}\right)\right) \cdot \cos h(2 K r \cdot B)+2 B\right. \\
& \left.\times \sin h(2 K r \cdot B)] \cdot \sin h\left(2 K r \cdot B \cdot h^{\prime} / H\right)\right\} \quad(5) \\
f_{3}= & +\rho_{3} \cdot E \cdot\left[-\left(2 \rho_{2}-\rho_{1} \cdot\left(1+\rho_{2}\right)\right) \cdot \sin h(2 K r\right. \\
& \left.\left.\times B \cdot h^{\prime} / h\right)+2 \rho_{2} \cdot B \cdot \cos h\left(2 K r \cdot B \cdot h^{\prime} / H\right)\right]
\end{aligned}
$$

$$
K r=[H \cdot(L+W)] /(2 \cdot L \cdot W)
$$

ここで， $H$ は成育室の高さ $(\mathrm{m}), L$ は奥行き $(\mathrm{m})$, $W$ は幅 $(\mathrm{m})$ である.

\section{2. 植物が成育室に設置された場合の照明計算法}

植物が成育室に設置された場合の照明モデルを Fig. 2 のように仮定した. すなわち, 植物体の高さ $\left(h_{\mathrm{p}}\right)$ の位置 に仮想床面を仮定し，植物体はこの仮想床面と同一平面 上に葉径が $D$ の円板として存在するとした。 また，仮 想床面は植物の成長に伴って天井面方向へ移動するとし た.このようにモデル化するとMoon の照明計算法が適

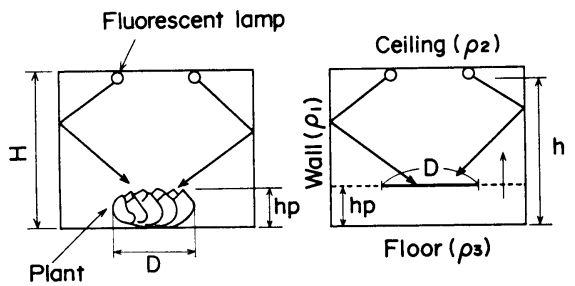

Fig. 2 Model for theoretical analysis of close illumination with plants present in growth room.

生物環境調節 (Environ. Control in Biol.) 


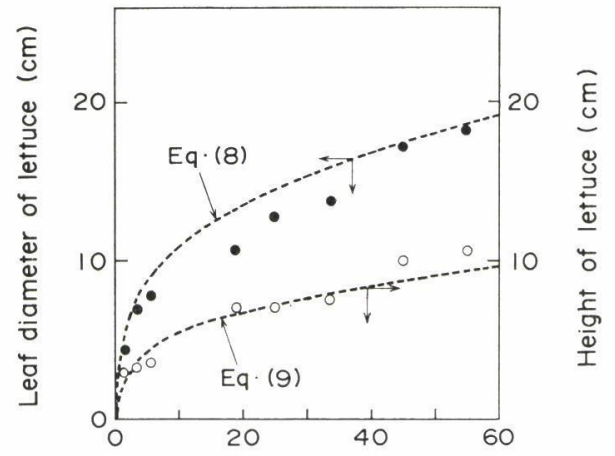

Fresh weight of lettuce (g/plant)

Fig. 3 Relatiorship between fresh weight, leaf diameter, and height lettuce (new-wave).

用でき，前述と同様に成青空の照明率抢よび光強度を算 出することができる.

このさい，植物の葉径 $(D)$ および高さ $\left(h_{\mathrm{p}}\right)$ は Fig. 3 に示したレタス（ニューウェーブ）の成育奏験加ら得た 実験式 $(8)$ 声よび $(9)$ 式から求めた。网中, 測定した 円相当葉径は長径と短径から求めた梤円の面箖から算出 した・なお（8）式に示したように，葉径は植物断面積 の $1 / 2$ 乗に比例し, 面積は生体重是の $2 / 3$ 乘に比例与る とした。

$$
\begin{aligned}
& D=D_{0} \cdot\left[(M / 50)^{2 / 3}\right]^{1 / 2} \\
& h_{\mathrm{p}}=D / 2
\end{aligned}
$$

ここで， $M$ は植物の生体重量 $\left(\mathrm{g} /\right.$ 個体)， $D_{0}$ は生体重 量が $50 \mathrm{~g}$ のとさ葉径で, ニューウェーブの場合, 約 $18 \mathrm{~cm}$ であった。

いっぽう, 仮想床面の反射率 $\left(\rho_{0}\right)$ は (10) 式之 (11) 式 から算出した。

$$
\begin{aligned}
& \rho_{0}=\rho \cdot \beta+\rho_{3} \cdot(1-\beta) \\
& \beta=\left(n \cdot S_{\mathrm{p}}\right) / S
\end{aligned}
$$

ここで， $\rho$ は植物莱の反射率(一)， $\rho_{3}$ は床面材の反射 率 (一), $\beta$ は床面積に対与る植物の占有面積比率 (一), $S_{\mathrm{p}}$ は植物個体の占有面積 $\left(\mathrm{cm}^{2}\right), n$ 注成有室に定植した 植物個体数， $S$ は床面積 $\left(\mathrm{cm}^{2}\right)$ で㐫る。

\section{実験装置および方法}

\section{1. 植物が成育室に設置されない場合の光強度の測定}

Fig. 4 亿示したように，形状の異なる A (幅 $1.2 \mathrm{~m}$, 奥行き $1.8 \mathrm{~m}$ ) および $\mathrm{B}$ (幅 $0.3 \mathrm{~m}$, 奥行き $1.2 \mathrm{~m}$ ) の平 面式のモデル成育室 (内面白色塗装) において, 天井面 に設置した $40 \mathrm{~W}$ 蛍光ランプ (三菱, FL40SW-50-EDL, $2,370 \mathrm{~lm} /$ 本）を炎れぞれ 15 本打よび 3 本点灯し，ラン

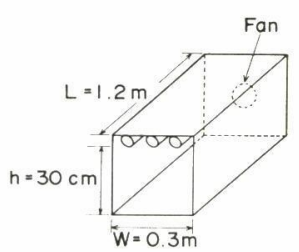

(a)

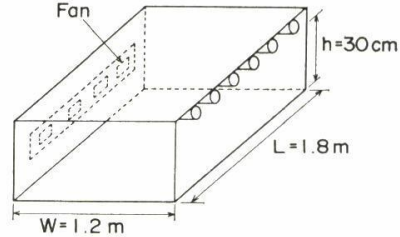

(b)
Fig. 4 Structure of plane growth room.

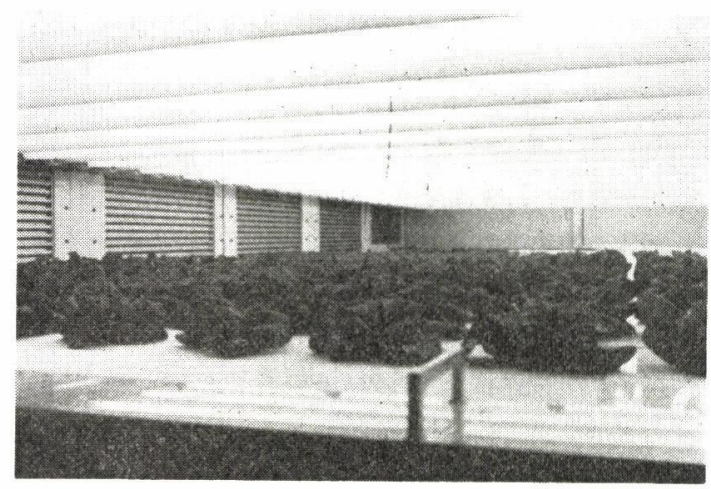

Fig. 5 Close illumination using fluorescent lamps.

プ高さが $20 \sim 30 \mathrm{~cm}$ の近接照明下で，床面照度とランプ 高さ $(h)$ の関係を調べた。なお, 照度は床面(白色発泡 スチロール）上の代表点（A：24 点，B：12 点）で測定 Lた.

また，Fig. 4(b) に示した成等室（ランプ高さ $30 \mathrm{~cm}$ )を Hルて, 成育空の高さ方向の光強度分布总調べた. 高さ 方向の光強度は, ランプ下面から $5 \mathrm{~cm}, 15 \mathrm{~cm}$ および 30 $\mathrm{cm}$ (床面) の位置での水平面照度老測定した。

さらに，Fig. 5 に示した近接照明方式の実験プラント 成育室（幅 $2.25 \mathrm{~m}$ ，奥行き $5.4 \mathrm{~m}$ ，ランプ高さ $30 \mathrm{~cm}$ ) において，試作した $110 \mathrm{~W}$ 巣光ランプ（形式 EX-3，約 $7,500 \mathrm{~lm} /$ 本) 42 本 (全灯), 28 本 (2/3 灯) および 21 本 (半灯) 点灯し, 床面上の代表点 (15 点)で照度を測定 した。

光強度は，照度センサー (LI-210SB, 370 770 nm) お よび光量子センサー (LI-190SB，400～700 nm)により測 定し, 床面（発泡スチロール）上の代表点で測定した照 度の平均值とした。照明率は, この平均床面照度を用い て（1）式から求めた。このとき,ランプ保守率は点灯時 間が約 100 時間後のランプを用いたので 1.0 とした。

白色塗装材 (膀面, 天井面) 打上び白色発泡スチ口ー ル板(床面)の反射率は，積分球（ライカー社製，1800-12， $400 \sim 1,100 \mathrm{~nm})$ により測定し，いずれも約 0.8 であっ 
た、いっぽう，壁面の反射率は通気口の空隙を考慮し， 約 0.6 とした. また，レタス葉（ニューウェーブ）の反

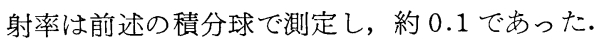

\section{2. 植物成育に伴う指標光強度変化の測定}

ランプ高さが $30 \mathrm{~cm}$ の近接照明方式の育苗成育室 ${ }^{8)}$ (幅 $2.16 \mathrm{~m}$, 奥行き $1.12 \mathrm{~m}$ ) において, 白色発泡スチロー ルの栽培パネルにレタス（ニューウェーブ）の苗（生体 重量約 $0.2 \mathrm{~g})$ を株間 $16 \mathrm{~cm} \times 16 \mathrm{~cm}$ で 91 株定植し, 光強 度 $310 \mu \mathrm{E} / \mathrm{m}^{2} / \mathrm{s}$ (110W 蛍光ランプ, 形式 $\mathrm{EX}-3,9$ 本点 灯, 約 7,500 lm/本) の条件下で約 12 日間水耕栽培し た。

実験期間中，毎日一定時刻に葉径を測定し，床面積 $S$ (栽培パネル面積)に対する植物の占有面積比率の経時変 化を測定した。光強度は，成育室中央部付近に定植した 4 個体の植物体の最上部での水平面照度（指標光強度） を照度センサーで測定し，これらの平均值とした。

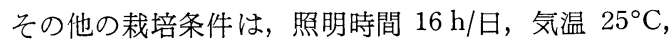
湿度 $70 \%, \mathrm{CO}_{2}$ 濃度 $350 \mathrm{ppm}$, 風速 $0.5 \mathrm{~m} / \mathrm{s}, \mathrm{EC} 1.3 \mathrm{mS}$ および $\mathrm{pH} 5.5$ に維持した。

\section{実験結果および考察}

\section{1. 植物が成育室に設置されない場合の近接照明特性}

\section{1-1. モデル成育室の照明率}

Fig. 6 は，Fig. 4 に示して平面式のモデル成育室 $\mathrm{A} お$ よび Bの照明率 $(f)$ とランプ高さ $(h)$ の関係を示したも のである. $h$ が $20 \mathrm{~cm}$ の近接照明の場合, $\mathrm{A}$ の $f$ は 1.5 と高い值を示した。 また， Bの $f$ も 1.1 と高い值を示し たが， $\mathrm{A} の ~ f に$ に比べて約 $27 \%$ 低下した. $h$ が $30 \mathrm{~cm}$ の 場合，Aおよび $\mathrm{B}$ お $f$ か $h$ が $20 \mathrm{~cm}$ の場合に比べてそ れぞれ約 $12 \%$ および $25 \%$ 低下した。このように，照明 率は室の形状によって変化し，とくにランプ高さに強く 依存することがわかった。

Fig. 7 は，Fig. 6 の結果を照明率 $(f)$ と室形状係数 $(K r)$ の関係としてまとめたものである．罒中, 実線は測 定結果を示し，破線は (1) ( 7) 式によるシミュレーショ ンの結果を示す. シミュレーションの結果と測定結果と はよく一致した． $f$ は成育室の大きさに関係なく $K r て$ 一義的に決定され，Kr が小さくなると顕著に増加した。

したがって，照明率を高めるには，成育室の $W$ およ び $L$ を大きくするか，または $H$ を小さくする必要があ るが， $K r$ は (7) 式に示したようにランプ高さと比例関 係にあり，ランプ高さを低くした近接照明が有効である ことがわかった。

\section{1-2. 実験プラントの照明率}

Fig. 5 に示した近接照明方式の実験プラントの成育室 $12(12)$

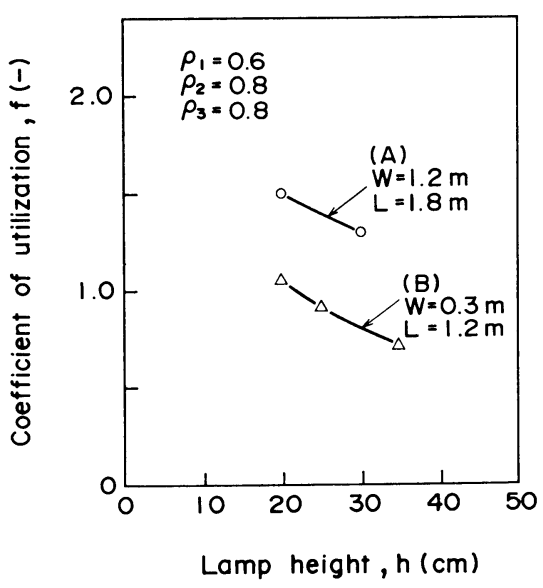

Fig. 6 Relationship between cosfficient of utilization $(f)$ and lamp height $(h)$.

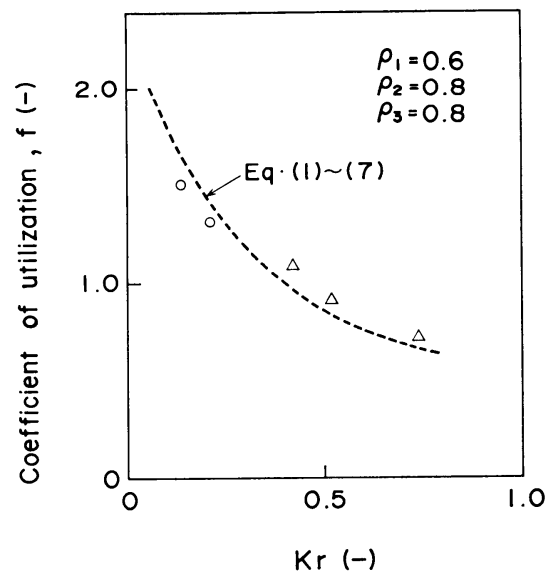

Fig. 7 Relationship between coefficient of utilization $(f)$ and room shape coefficient $(K \gamma)$.

(ランプ高さ $30 \mathrm{~cm}$, 床面積 $12 \mathrm{~m}^{2}$ ) において，試作した $110 \mathrm{~W}$ 䖝光ランプ (形式 EX-3) を42 本点灯 (全灯) した 場合，床面の平均光強度は約 $45 \mathrm{klx}\left(650 \mu \mathrm{E} / \mathrm{m}^{2} / \mathrm{s}\right)$ の高 光強度が得られた。点灯本数を 28 本および 21 本に減少 した場合，床面の平均光強度はそれぞれ約 $30 \mathrm{klx}(440$ $\left.\mu \mathrm{E} / \mathrm{m}^{2} / \mathrm{s}\right)$ および約 $22 \mathrm{klx}\left(330 \mu \mathrm{E} / \mathrm{m}^{2} / \mathrm{s}\right)$ となり，ほぼ ランプの点灯本数の減少量に比例して低下した ${ }^{8}$.

成育室の照明率 $(f)$ は，これらの平均床面照度を用い て，(1）式から算出すると約 1.7 の高い值を示した.こ のとき, Fig. 7 に示したシミュレーションによる $f$ は， 室形状係数 $(K r)$ が 0.13 であるので約 1.8 となり，測 定結果とよく一致した.

一方，高圧ナトリウムランプなどの高輝度ランプの場 生物環境調節 (Environ. Control in B:ol.) 
合, 熱線による葉焼けの問題や光強度分布の均一化など からランプ高さは $1 \mathrm{~m}$ 以上を必要とし, 照明率は通常 $0.5 \sim 0.7$ として設計される. したがって，この成育室の 照明率は, 高圧ナトリウムランプなどの高輝度ランプよ りも約 3 倍高くなり，蛍光ランプによる近接照明方式に より成育室の光利用効率が著しく向上することが明らか となった。

なお, レタスの生産に要する照明電力量は, 前報で報 告した植物工場実験プラントを用いて求めた結果 ${ }^{8)}$ ，生 体重量が $75 \mathrm{~g} /$ 株の場合, 約 $1.1 \mathrm{kWh} /$ 株（総電力消費量 約 $2.5 \mathrm{kWh} /$ 株）となり, 従来の高圧ナトリウムランプ などの高輝度ランプの約 $1 / 2$ に低減された ${ }^{13)}$. いっぽう， 育苗に要する照明電力消費量は, 生体重量が $10 \mathrm{~g} /$ 株お よび $0.25 \mathrm{~g} /$ 株の場合, それぞれ約 $0.3 \mathrm{kWh} /$ 株および $0.06 \mathrm{kWh} /$ 株であった. このように，蛍光ランプを用い た近接照明により，省照明電力でレタスを生産または育 苗できることが実証された。

\section{1-3. 成育室の高さ方向の光強度分布}

Fig. 8 は, Fig. 4(b) に示した成育室（ランプ高さ 30 $\mathrm{cm})$ において， $40 \mathrm{~W}$ 蛍光ランプ 15 本を点灯したときの $W=60 \mathrm{~cm}$ (中央部) における高さ方向の光強度 (水平面 照度）分布を示したものである. 図中, $h^{\prime}$ はランプ下面 からの距離を示す. 縦軸は $h^{\prime}=5 \mathrm{~cm}, L=90 \mathrm{~cm}$ での照 度を 100 としたときの相対光強度を示す.

光強度は，いずれの $h^{\prime}$ においても $L$ の両端（苗の供 給と収穫のために陌間が大きい）で低くなる傾向が見ら れたが， $h^{\prime}$ が $30 \mathrm{~cm}$ (床面)，15cm (1/2h) および $5 \mathrm{~cm}$ で，それぞれ 21.5，23 および $25 \mathrm{klx}$ であった。この ように, 近接照明の場合, 周囲面の反射により，成育室 の高さ方向の光強度分布は, $h^{\prime}=5 \sim 30 \mathrm{~cm}$ の範囲にお いて，80〜100 の範囲で均一であることがわかった。 た，Fig. 9 に示したように，シミュレーションの結果に おいても $h^{\prime}=7.5 \sim 30 \mathrm{~cm}$ および床面反射率 $\left(\rho_{3}\right)$ が $0.1 \sim$ 0.8 の範囲において, 高さ方向の光強度は約 $7 \%$ 以内の 差で均一であった。

以上のように，蛍光ランプによる近接照明の場合，成 育室の高さ方向 (ランプ高さ $30 \mathrm{~cm}$ ) の光強度は, ランプ からの距離の 2 乗に反比例する関係が成立せず，床面か らの距離が $0 \sim 25 \mathrm{~cm}$ の範囲において，20\%以内の差で 均一であった。

\section{1-4. 照明率に及ぼす周囲面の反射率の影響}

Fig. 10 は， $f$ に及ぼす周囲面の反射率の影響をシミュ レーションした結果を示したものである，ただし，他の 2 面の反射率はいずれも 0.8 とした. $f$ は $\rho_{1}, \rho_{2}, \rho_{3}$ の 減少に伴って低下したが，天井面の反射率 $\left(\rho_{2}\right)$ の減少に

Vol. 30, No. 1 (1992)

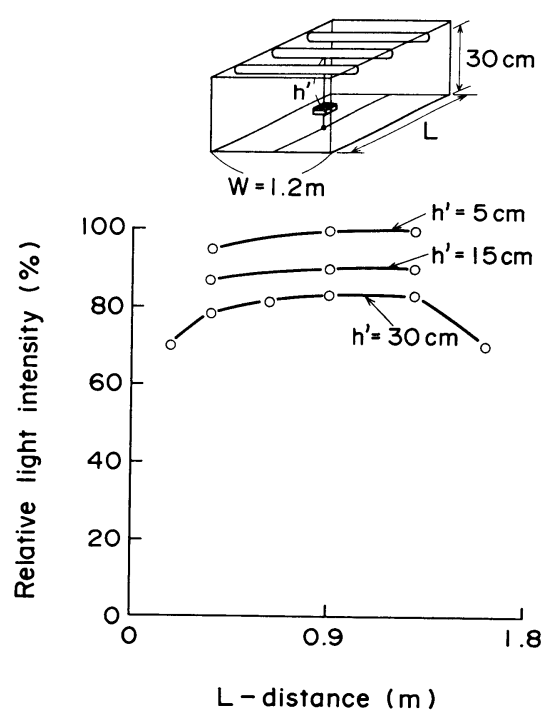

Fig. 8 Light intersity in the height-direction of growth room.

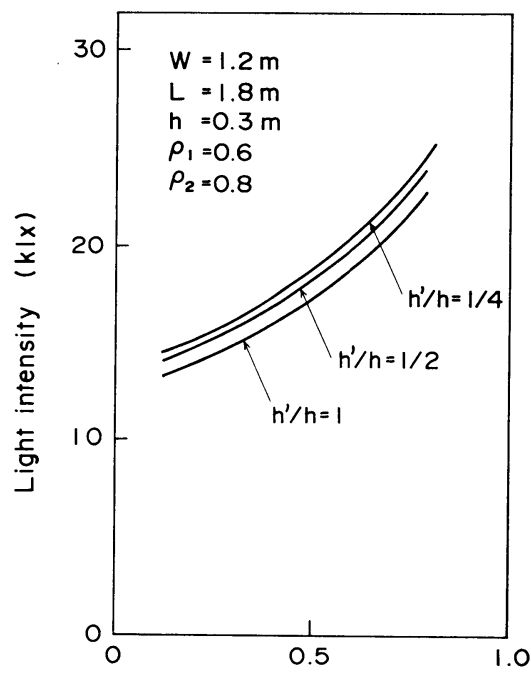

Reflectance of floor, $\rho_{3}(-)$

Fig. 9 Relationship between light intensity in the height-direction and reflectance of floor.

より最も著しく低下した.

このように，天井面の反射率が照明率に対して最も強 く影響し，照明率を高めるためには，天井面を高反射率 とすることが有効であることがわかった。

\section{2. 成育に伴う指標光強度の変化}

Fig. 11 は，成育室に定植したニューウェーブおよび 


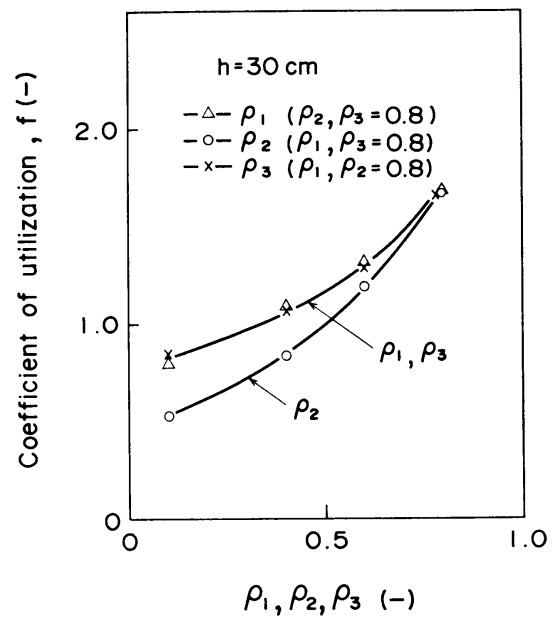

Fig. 10 Effects of reflectance of wall, ceiling, and floor on coefficient of utilization $(f)$.

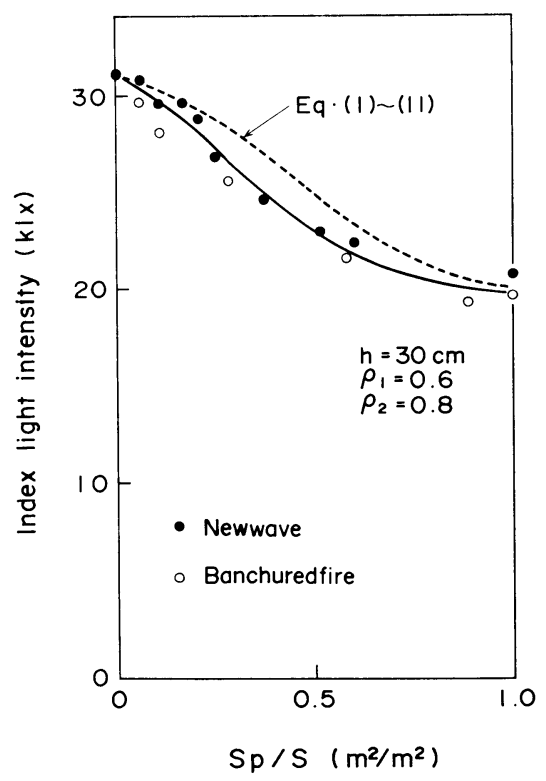

Fig. 11 Relationship between index light intensity and ratio of plant area occupation to floor area.

晚抽レッドファイヤーの成長に伴ら指標光强度（植物体 最上部での水平面照度)の経時変化を示したものである. 図中, 実線は測定結果を示し, 破線は (1) （11) 式によ るシミュレーションの結果を示す. 測定結果とシミュ レーションの結果はおおむね一致し, 植物の成長に伴っ て指標光強度は著しく低下する傾向が認められた。床面 全体が植物で覆われた場合の指標光強度は, 植物が設置 されない場合の床面照度にくらべてニューウェーブおよ

14 (14)
び晚抽レッドファイヤーでそれぞれ約 35\% および $33 \%$ 低下した。このように, 成長に伴う植物の占有面積比率 の增加により, 指標光強度は著しく低下寸ることがわか った。

以上の結果から，一定の光強度条件を維持するには， 成育に伴ってランプの点灯本数を増加するなどの方法に より指標光強度が低下しないようにする必要があると考 えられる。

\section{摘要}

蛍光ランプと床面の距離(ランプ高さ)を数十 $\mathrm{cm}$ に近 接させ内面を白色塗装 (反射率 0.8 ) し, 反射光を有効に 利用した近接照明の特性を調べ，以下の知見を得た。

（1）照明率（成育室の光利用効率を示す係数）のシ ミュレーションは測定結果とよく一致した。照明率は室 形状係数が小さくなると著しく増加した．室形状係数は ランプ高さと比例関係にあり，照明率を高めるためには ランプ高さを低くした近接照明が有効であることがわか った。

（2）ランプ高さ $30 \mathrm{~cm}$ の近接照明方式の成育室 (幅 $2.25 \mathrm{~m}$ ，奥行き $5.4 \mathrm{~m}$ ) において， $110 \mathrm{~W}$ 蛍光ランプを 42 本点灯した場合, 床面の平均光強度は約 $45 \mathrm{klx}$ の高 光強度が得られた.このとき, 照明率は約 1.7 となり, 高圧ナトリウムランプなどの高輝度ランプの場合よりも 約 3 倍高くなった.このように, 蛍光ランプを用いた近 接照明により成育室の光利用効率を著しく向上できるこ とが明らかとなった。

（3）成育室 (ランプ高さ $30 \mathrm{~cm}$ ) の高さ方向の光強 度は, 床面からの距離が $0 \sim 25 \mathrm{~cm}$ の範囲において, 約 $20 \%$ 以内の差で均一であった。

（4）照明率之壁面, 天井面, お上び床面の反射率の 関係をシミュレーションした結果, 照明率を高めるに は，天井面を高反射率とするのが有効であることがわか った。

（5）成育室に植物が設置された場合の指標光強度 (植物体最上部の水平面照度)のシミュレーションと測定 結果は打打む永一致した。指標光強度は, 床面全体が植 物（レタス)で覆われたとき, 初期の床面照度の約 $35 \%$ 低 下した，一定の光強度条件を維持するには, 成長に伴っ てランプの点灯本数を增加するなどの方法により指標光 強度が低下しないようにする必要がある.

本研究を遂行するにあたり，光源を試作していただい た三菱電機(株)生活システム研究所安西良矩氏, 三橋征 寿郎氏に㴬意を表する。また，本論文作成にあたり，ご 生物環境調節 (Environ. Control in Biol.) 
助言を賜った大阪府立大学相賀一郎教授に感謝いたしま 于.

\section{文献}

1）稲田勝美. 1984. 人工光と植物の生育. 「光と植物生育」 （稲田勝美編）236-306, 養賢堂, 東京.

2）池田 彰 ·江崎謙治・ 中山繁樹. 1985. 全方向光照射にお ける植物生育特性（I）. サラダナ生育速度に及ぼす光強 度, $\mathrm{CO}_{2}$ 濃度および気温の影響. 生物環境調節 22: 71-77.

3）池田 彰. 中山繁樹. 山崎広義. 安西良矩. 1985. パルス 光照射光源とその植物栽培への適用. 計測自動制御学会論 文集 21: 107-109.

4）池田 彰・江崎謙治・河相好孝 - 中山繁樹. 1987. 全方向 照射における植物生育特性（II）. 蛍光ランプによる近接 光照射下でのサラダナ生産に要する照明電力消費量. 生物 環境調節 25: 1-5.

5）池田 彰 - 中山繁樹 - 北宅善昭 - 矢吹万寿. 1988. 植物工 場における物質生産の研究 (1). サラダナの光合成と日長, 光強度および $\mathrm{CO}_{2}$ 濃度の関係. 生物環境調節 26: 107-112.

6) 池田 彰. 中山繁樹 - 北宅善昭 - 矢吹万寿. 1988. 植物工
場における植物生産の研究 (2). コカブの光合成と日長, 光強度および $\mathrm{CO}_{2}$ 濃度の関係. 生物環境調節 26: 113-117.

7) IKedA, A., S. NAKAYAMA, Y. KitAYA, and K. YABUKI. 1987. Effect of photoperiod, $\mathrm{CO}_{2}$ concentration, and light intensity on growth and net photosynthetic rates of lettuce and turnip. Acta Hortic. 229: 273-282.

8）谷村泰宏・池田 彰・江崎謙治・河相好孝 - 中山繁樹 - 岩 尾憲三・蔭山裕之. 1991. 蛍光ランプを用いた人工光型植 物工場の研究. 生物環境調節 29: 81-88.

9）鶴岡 久. 金子忠男·高辻正基. 1984. 立体式植物工場の 照明設計法. 計測自動制御学会論文集 20: 734-739.

10) Ruthner, N. 1981. High efficient plant radiation within Ruthner crop production systems. Acta Hortic. 128: $197-202$.

11）藤原義輝 ·斉藤辰彌. 1955 . 相互反射. 「照明設計」 (“Lighting Design" Moon, P. and D. E. Spencer 著) 114-137, 技報堂, 東京.

12）石野幸三. 1972. 「室内照明設計法」88-108, 森北出版, 東京.

13）伊東 正. 1986. 植物の工場的生産一の実践的アプローチ. 農業および園芸 61: 174-180. 